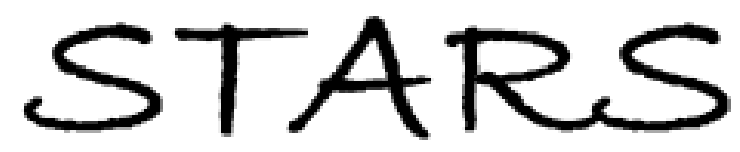

University of Central Florida

STARS

Faculty Bibliography 2010s

Faculty Bibliography

$1-1-2012$

\title{
Fire hazard and other safety concerns of photovoltaic systems
}

Neelkanth G. Dhere

University of Central Florida

Narendra S. Shiradkar

University of Central Florida

Find similar works at: https://stars.library.ucf.edu/facultybib2010

University of Central Florida Libraries http://library.ucf.edu

This Article is brought to you for free and open access by the Faculty Bibliography at STARS. It has been accepted for inclusion in Faculty Bibliography 2010 s by an authorized administrator of STARS. For more information, please contact STARS@ucf.edu.

\section{Recommended Citation}

Dhere, Neelkanth G. and Shiradkar, Narendra S., "Fire hazard and other safety concerns of photovoltaic systems" (2012). Faculty Bibliography 2010s. 2484.

https://stars.library.ucf.edu/facultybib2010/2484

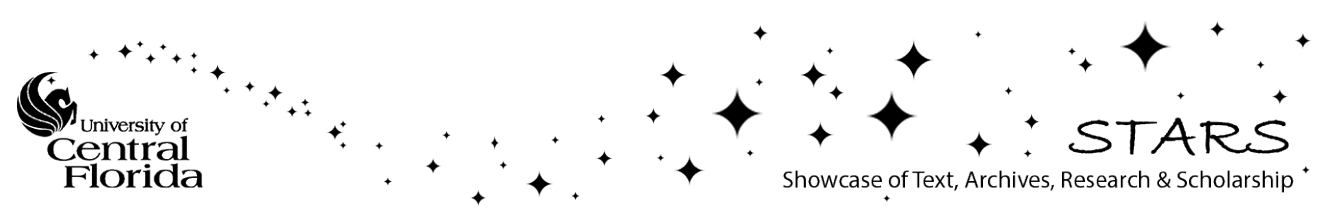




\section{Photonics for Energy}

SPIEDigitalLibrary.org/jpe

\section{Fire hazard and other safety concerns of photovoltaic systems}

Neelkanth G. Dhere

Narendra S. Shiradkar 


\title{
Fire hazard and other safety concerns of photovoltaic systems
}

\author{
Neelkanth G. Dhere and Narendra S. Shiradkar \\ University of Central Florida, Florida Solar Energy Center, 1679 Clearlake Road, \\ Cocoa, Florida 32922 \\ dhere@fsec.ucf.edu
}

\begin{abstract}
Photovoltaic (PV) modules are usually considered safe and reliable. But in case of grid-connected PV systems that are becoming popular, the issue of fire safety of PV modules is becoming increasingly important due to the employed high voltages of 600 to $1000 \mathrm{~V}$. The two main factors, i.e., open circuiting of the dc circuit and of the bypass diodes and ground faults that are responsible for the fire in the PV systems, have been discussed in detail along with numerous real life examples. Recommendations are provided for preventing the fire hazards such as designing the PV array mounting system to minimize the chimney effect, having proper bypass and blocking diodes, and interestingly, having an ungrounded PV system. (C) 2012 Society of Photo-Optical Instrumentation Engineers (SPIE). [DOI: 10.1117/1.JPE.2.022006]
\end{abstract}

Keywords: photovoltaic module; fire hazard; safety.

Paper 12013SSP received Feb. 28, 2012; revised manuscript received Oct. 31, 2012; accepted for publication Nov. 7, 2012; published online Dec. 14, 2012.

\section{Introduction}

Photovoltaic (PV) systems are typically believed to be reliable and safe. Early systems were mostly standalone, and low voltage, with one or few modules and were used mostly for battery charging in remote locations. PV cells and modules have been considered safe because they can be operate anywhere on their I-V curve safely. Since mid-90's, the proportion of grid-connected PV systems has been increasing. The year 2011 was expected to be the first year in which the utility-scale photovoltaics would rank as the largest segment of the US solar market. ${ }^{1}$ It was estimated that more utility scale PV will be installed than the residential and commercial PV combined. ${ }^{1}$ It is essential to increase the system voltage to save transmission losses. Thus, for economic reasons, grid-connected systems that fall under the US National Electric Code (NEC) are operated at high voltages of up to $600 \mathrm{~V}$ in USA and up to $1000 \mathrm{~V}$ in Europe and elsewhere. Moreover, utility scale systems behind the fence in USA do not fall under NEC and can use higher voltages.

When all cells connected in series in a well matched PV circuit are illuminated uniformly, all will generate an equal amount of current and their voltages will get added. One danger of overheating leading to fire arises due to partial or full shading of individual cells connected in series. The partially or fully shaded cell will generate a lower or no current, respectively, and act as a reverse biased diode. $\mathrm{c}$-Si modules can be shaded easily by objects and persons while thin-film modules can be affected by rectilinear shadows covering cell row(s). In an attempt to maintain the current in the series connected circuit, the total voltage of the illuminated cells in series can get applied to the shaded cell as a reverse bias. Bypass diodes are used to avoid accidental application of high reverse voltages to individual cells within series connected strings of PV modules. Similarly, blocking diodes are used in PV module arrays to avoid accidental application of forward voltage bias to individual series connected strings of PV modules that are in parallel to the rest of the system. In fact, many systems do not use blocking diodes. They were mostly used to prevent batteries from discharging through the modules. Thus, proper choice of the bypass and blocking diodes as well their adequate testing are important safety precautions.

0091-3286/2012/\$25.00 @ 2012 SPIE 


\section{Junction Breakdown and High Localized Currents}

The reverse current of a solar cell is usually negligibly small until a breakdown occurs after which the current can increase dramatically leading to overheating and fire hazard. It is instructive to consider the junction breakdown of a reverse biased cell. The Zener diode is prepared with both highly doped regions $p+$ and $n+$. The high doping makes the depletion region very narrow making it easy for the electrons to tunnel through. In the avalanche diode, the highly accelerated charge carriers keep generating increasing charge carrier densities by collisions leading to the avalanche effect. The avalanche breakdown with a negative resistance occurs when the increasing generation charge carrier densities by collisions is assisted by the thermal carrier generation by increasing temperature. Breakdown voltages of Zener diodes are usually very low. PV cells usually have a highly doped $n+$ emitter region whereas the $p$-type base region is lightly doped so as to spread the charge collection region. Consequently, the breakdown will occur by the avalanche process with or without the negative resistance region. Whenever protection is provided by properly chosen and installed diodes, the main danger will arise from cells with low shunt resistance where high localized currents can flow well before junction breakdown.

\section{Shading and Reverse Bias Conditions}

Reverse biasing of a shaded cell in a PV circuit is usually avoided by using a bypass diode that will allow the photogenerated current of illuminated cells to bypass the shaded cell. In practice, the bypass diodes limit the reverse voltage across a cell, they do not eliminate it completely. For example, if there is 1 diode per 20 cells that is a typical configuration, the reverse voltage will be limited to the forward peak power voltage of the other 19 cells (that is approximately $19 \times 0.5 \mathrm{~V}$ ). This solution could become inadequate if the bypass diode is unable to handle the large current and fail. When the bypass diode becomes open circuited, the dangerous condition of early JPL Block systems where no bypass diodes were employed is reached. In those early JPL Block high-power systems, modules began suffering from hot spot failures. One example was a $60 \mathrm{~kW}$ high voltage system at Mt. Laguna, California. Part of array built with solar power modules [40- to 4-in. diameter Czochralski (CZ) c-Si cells in series] with no bypass diodes. Some of the high power and high voltage systems resulted in excessive heating due to arcing or resistive heating and even caught fire. Consequently, the Hot Spot Test was added in the JPL Block V Test Protocol. The problem can become increasingly severe if successive bypass diodes continue to fail. The late Chuck Whitaker highlighted the severity of such an occurrence and serious hazard it can pose by suddenly shouting "fire" in the midst of his presentation. On the other hand, a short circuit failure of the bypass diode will only lead to a loss of the power generated by the cells protected by that diode. TamizhMani and Sharma ${ }^{2}$ have evaluated the hot spots in PV systems and compared the three test methods used in the industry to identify and address this issue. The methods are based on the UL 1703 (intrusive) standard, ASTM E2481-06 (nonintrusive) standard, and IEC 61215 edition 2 (nonintrusive) standard. They have concluded that ASTM E2481-06 method appears to be the best method for accurate cell selection and stress testing procedures.

\section{Open Circuits}

One documented case of PV fires is the occurrence of an open circuit where the system voltage can occur across a small gap. Such discontinuities in the conduction path in a high voltage dc system can initiate electrical arcing especially if the gap is narrow enough to initiate an arc. If the two electrodes are mechanically held in place, the arc may continue for a long time.

An interesting early example of the creation of a open circuit and ground fault within the PV circuit of the module itself is provided in the following: considerable degradation was observed in negatively-biased, first-generation, framed a-Si:H thin-film photovoltaic (PV) modules. In the late 80's and early 90's, an array of 640 a-Si:H PV modules was installed with a tilt of $\sim 25$ deg towards the south by the Florida Power Corp at Orlando, FL in collaboration with researchers of the Florida Solar Energy Center (FSEC). FSEC researchers also monitored the system. Modules 
were fabricated with fluorine-doped tin oxide $\left(\mathrm{SnO}_{2}: \mathrm{F}\right)$ transparent conducting oxide (TCO) layers on superstrate glass. The system consisted of columns of eight modules having open circuit voltage, Voc of $20 \mathrm{~V}$, and peak power voltage, Vm of $15 \mathrm{~V}$ connected in parallel. Sixteen such columns were connected in series. Five such rows were connected in parallel. The array operational voltage was $300 \mathrm{~V}$ dc. Five of the degraded modules were chosen for analysis with the help of Dr. Gobind Atmaram, FSEC. Bar graph type degradation was found to be caused by moisture ingress and corrosion; inward and sideways (Fig. 1). Either the electric shorting caused cracks in glass or crack in the glass caused arcing (Fig. 2). It can be seen that the corrosion starts from the edges, but interestingly the cracks that have been developed as a result of corrosion were acting as new corrosion sites, thus accelerating the process. Aluminum frames had been damaged in several places (Fig. 3).

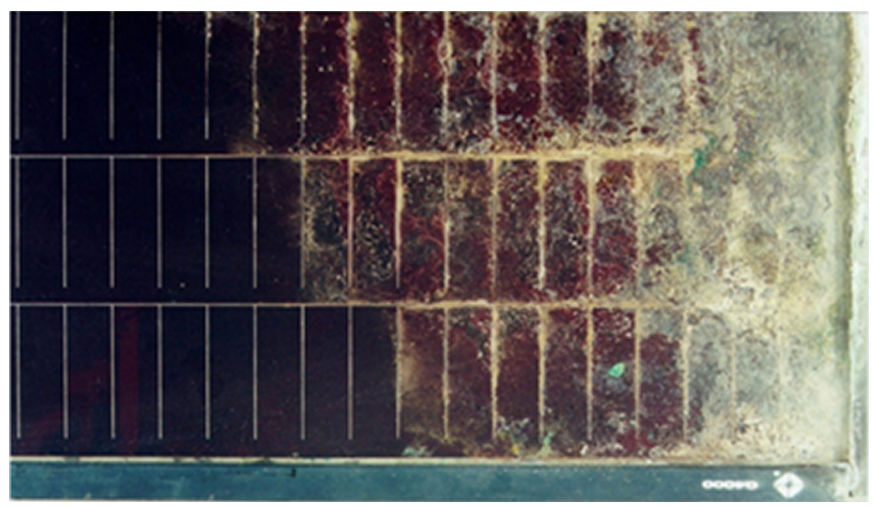

Fig. 1 Bar graph-type degradation caused by moisture ingress and corrosion; inward and sideways.

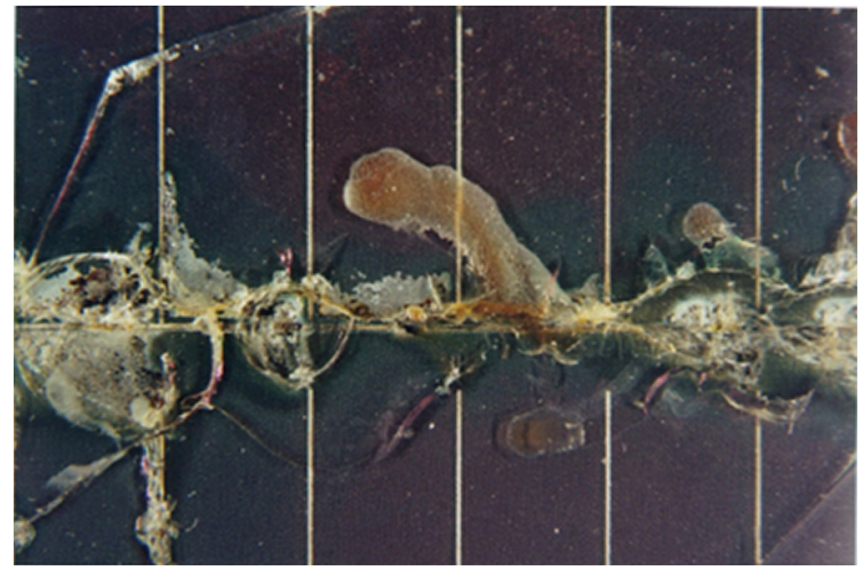

Fig. 2 Electric shorting caused cracks in glass or cracks in glass caused shorting.

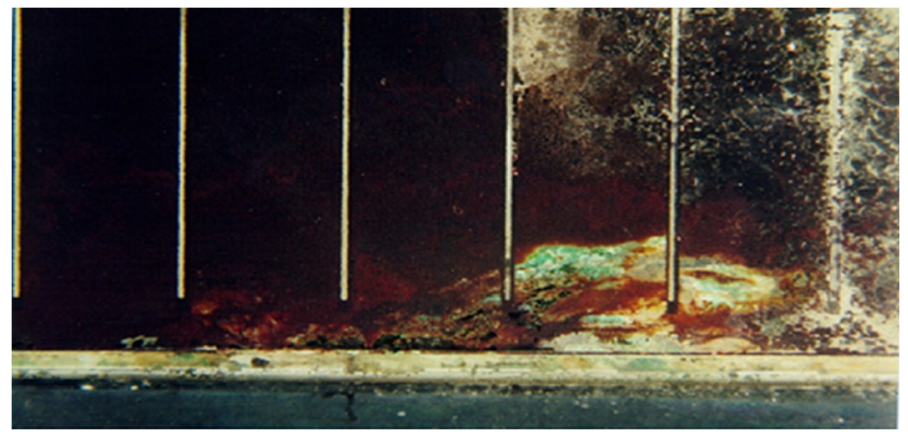

Fig. 3 Damage caused to the aluminum frame due to corrosion. 


\section{Ground Fault and Arcing in PV Modules}

Another cause of fire in a PV system is the development of a ground fault. PV modules are supposed to provide high resistance stand-off between the electric circuit and the ground plane. Just as any other electrical circuit, a low resistance path to ground can lead to overheating, arcing, and fire.

The worst problem seen in the system described in Sec. 4 was caused when the corrosion reached the junction box, created a ground fault and resulted in arcing. Here the arc was so intense that in a large section of the glass-to-glass module, the glass melted and the molten glass left a $\sim 7$-in. long gaping hole that was large enough to pass a fist through (Fig. 4). Other researchers may have interpreted this as another example of the open circuit case. However, interpretation of a possible ground fault is based on the results of the subsequent destructive testing. Samples extracted from other modules of this installation showed that the corrosion caused by high voltage bias in the hot and humid conditions of Florida resulted in the complete destruction of the p-i-n diode structure leaving behind disintegration by-products. Possibly this disintegrated material provided a conducting path for the system voltage to reach all the way up to the junction box resulting in a massive ground fault which did not open up until all the material was molten and fell to the ground. The molten glass that fell down did not lead to fire because of the gravel on the ground (Fig. 5). Such problems had been diagnosed as being caused by the thinfilm circuit reaching all the way to the edge and were resolved by deleting the film near the edge all around the periphery, (the so-called edge-delete) in the subsequent production.

The arc creates high temperature plasma which acts as a low impedance path. Ulrike Jahn has suggested that the risk of arcing from the cell-string connector and clamp-cable connection is highest because of the moderate probability of their occurrence and highly dangerous nature due to the possibility of long-burning electrical arcs. ${ }^{3}$ Once an arc is struck, it is difficult to extinguish as long as the electrical power is being applied. If it is sustained over a long period it can ignite

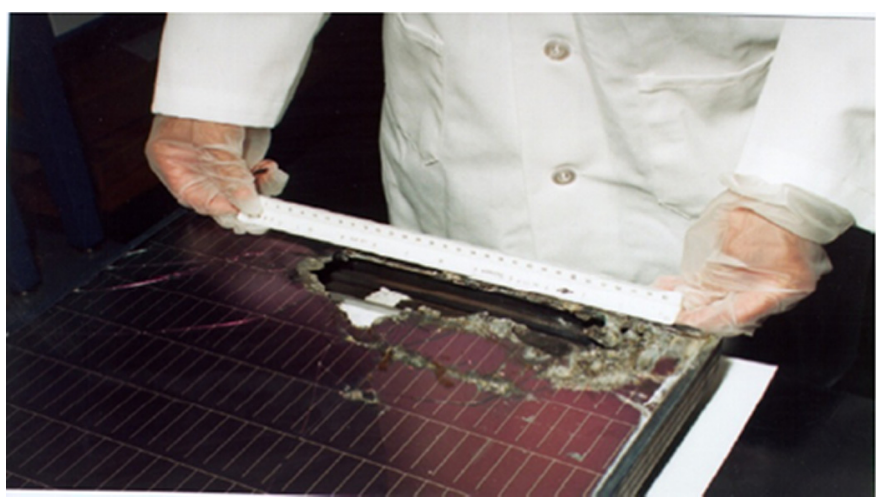

Fig. 4 Arcing and molten glass as a result of corrosion reaching the junction box left a $\sim 7$ in. long gaping hole, large enough to pass a fist through.



Fig. 5 Molten glass fell down, but did not lead to fire because of gravel on the ground. 


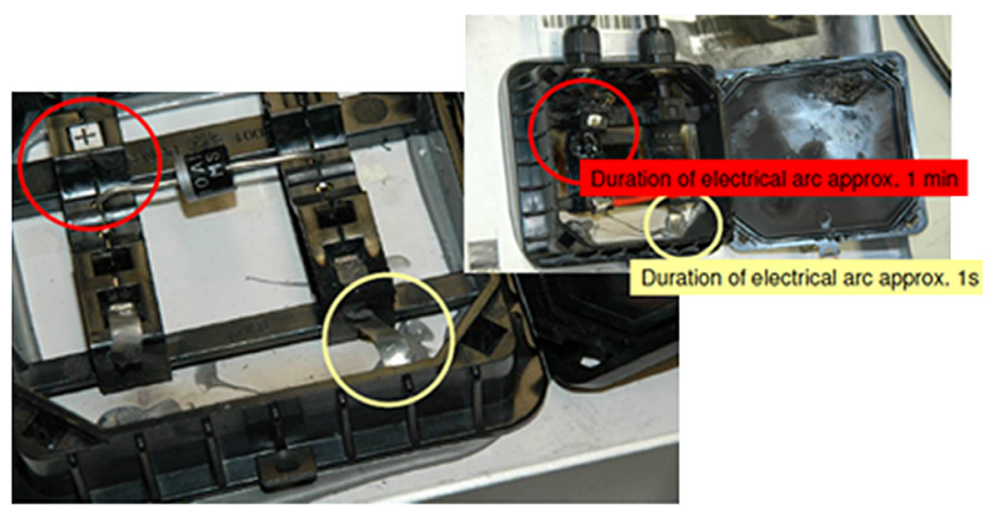

Fig. 6 Effect of arcs with different lifetimes inside the junction box. ${ }^{3}$

surrounding materials. The secondary risk from arcing is dependent on the product of arc power $\times$ arc lifetime. The arc power is determined by the current-voltage combination involved, while the arc lifetime is dependent on the fault location and the mass, conductivity and flammability of surrounding materials. Figure 6 shows the effect of arcing with different lifetimes inside the junction box. ${ }^{3}$ The damage caused by arc with 1 second duration was insignificant compared to that caused by the arc with 1 min lifetime. In this regard, PV systems are difficult to switch-off at will. The power will be continued to be generated as long as the PV cells in the modules are illuminated. For example, during the "Desert Storm" bombing raids, several parts of Baghdad remained illuminated by the PV street lighting with battery back-up. It took some time to place switches on these individual units. At times, ground faults can be created by an installation error and can have serious consequences. It is difficult to stop the photogenerated current from flowing in ground loops until a component gets very hot, then melts or burns. Care should be taken to avoid the penetration of the modules by fasteners used during the installation. In any case, extreme caution should be exercised to avoid shorting.

The pictures in Figs. 7 and 8 show the junction box failures caused by arcing.

\section{Ground Fault Prevention and Arc Fault Detection}

High $(>300 \mathrm{~V})$ voltage de system can lead to an arc. Any open circuit in a series circuit or an additional ground fault in a parallel circuit can cause arcing. Arcs have been observed in most components utilized in PV systems. In the wrong situation arcs can be sustained for a significant amount of time and can cause many materials to catch fire. Solutions include good selection

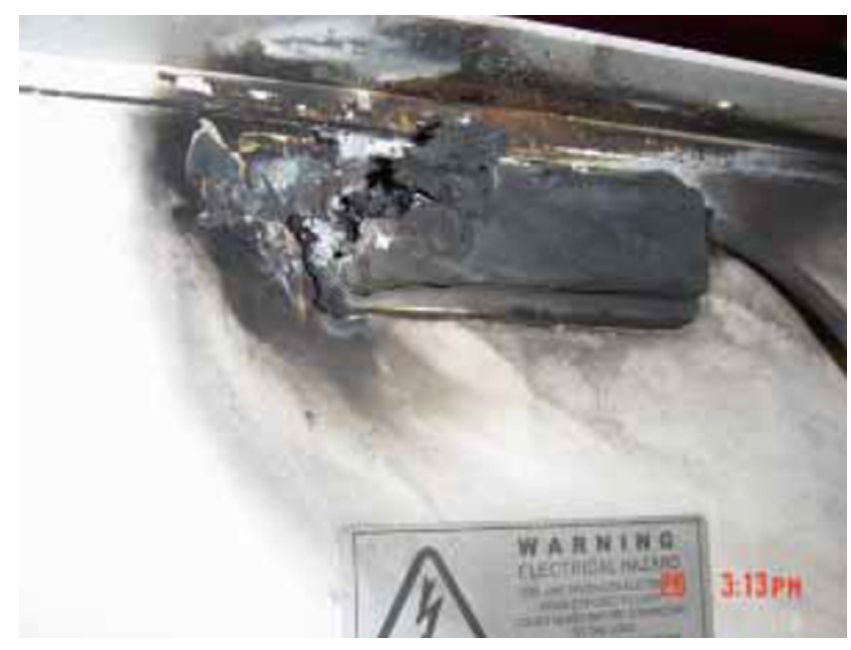

Fig. 7 Junction box failure caused by arcing. ${ }^{4}$ 


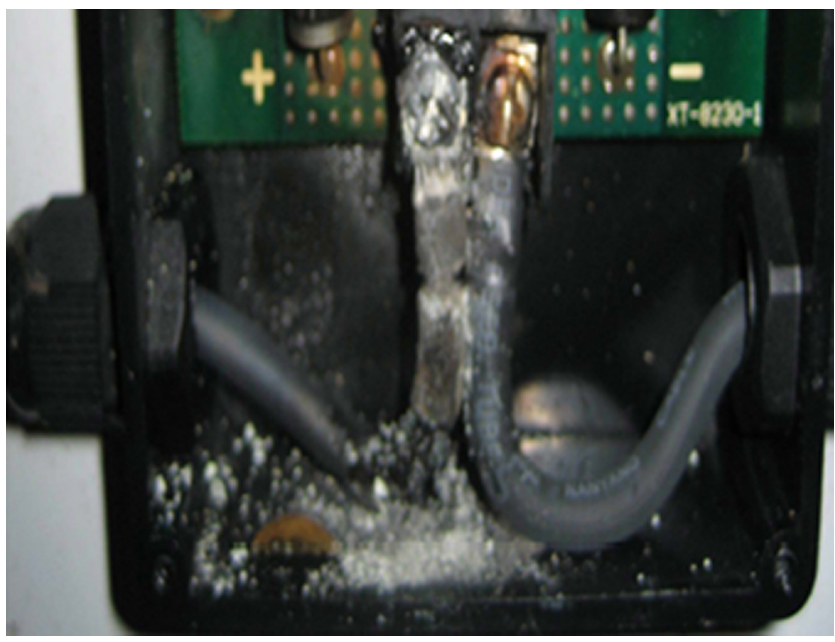

Fig. 8 Junction box failure. Courtesy: John Wohlgemuth, NREL.

of components, system design, and installation using certified mounting and maintenance practices. Six sigma is not good enough when result of error is formation of an arc. Use of redundant connections is one solution.

Figure 9 shows the formation of a series arc. There is a need for a dc arc detector to protect sensitive PV systems. Series arcs are easy to detect and to stop by opening the circuit. For the series arcs, the NEC 2011 states that the arc fault detector is required for building mounted PV.

Parallel arcs can be formed when a second ground contact is formed in addition to an existing ground connection (Fig. 10). Once formed the parallel arc is very difficult to stop. In fact, the solution is counterintuitive because what is required is to remove the existing ground connection.

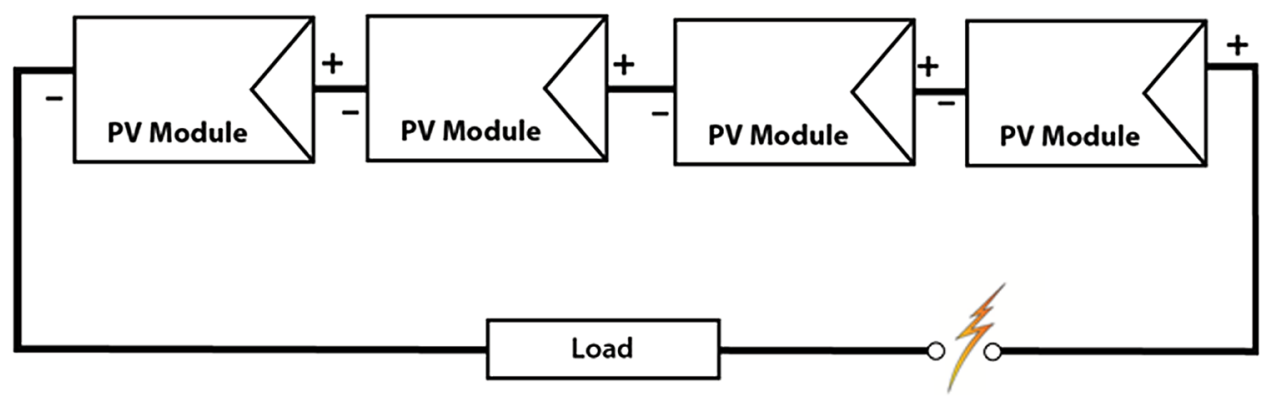

Fig. 9 Formation of a series arc.

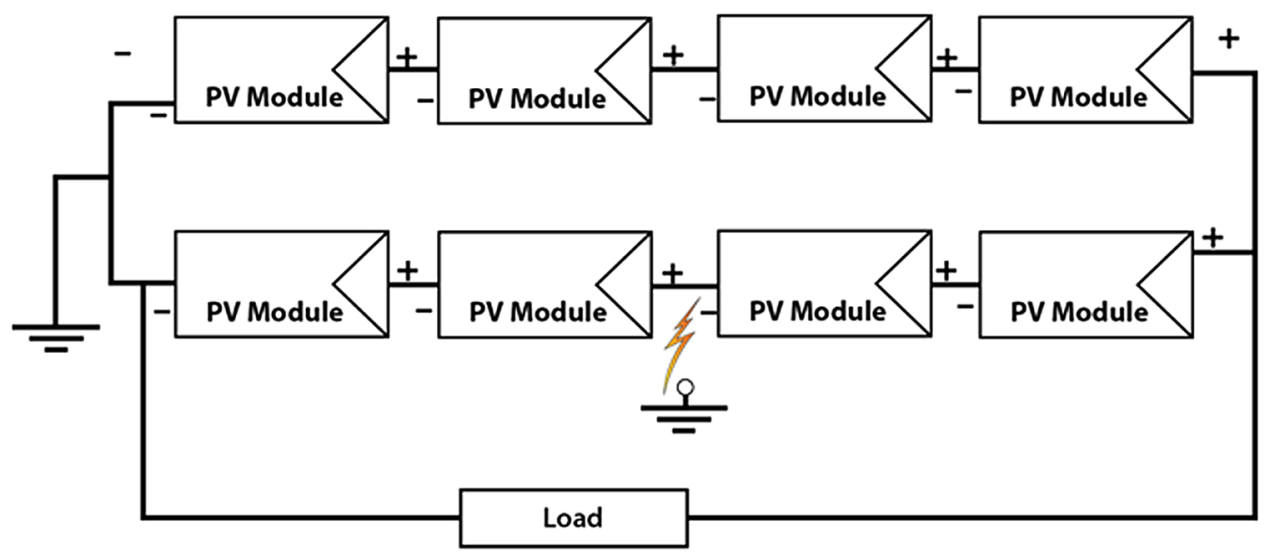

Fig. 10 Formation of parallel arc. 
Since the parallel arcs are not easy to detect or stop, it is easier to use ungrounded arrays and detect the ground faults themselves. In the United States, it is customary to ground either the positive or negative lead of a PV system. Any ground fault can immediately lead to a dangerous situation. Grounding of the array circuit may actually increase the potential for this type of fault. Two ground faults are required to cause a problem in an ungrounded circuit. Consequently, in a grounded array, it only takes one ground fault to cause current flow in a ground loop. The solution may be not to ground any active circuit element of the PV system. In fact, the present draft of the NEC 2014 forbids the grounding of the active circuit for systems above 300 volts. Thus, if neither of the leads nor any other part of the PV system is connected to ground and moreover, if a reliable ground fault detector is included, the first instance of ground fault can be detected and repaired without any hazard of overheating and fire. Any metal frames and support structures will still need to be grounded. The ground fault detector then measures the leakage current between the active circuit and the ground plane within the mounting structure. At present, $\mathrm{dc}$ ground fault detection is already required on certain PV systems that are mounted on a building and, of course, on building integrated PV systems. Additionally, a well-designed PV system must include an arc fault detector. The arc fault detectors now under development will detect arcs only due to open circuits and not those due to ground faults. It must be noted that some arc fault detection systems using frequency content of the string for detection may not function well. ${ }^{5}$ Remote arc detection is faced with two challenges: one is of missed or delayed detection due to filtering in PV components (e.g., modules, connectors, bypass diodes) and the other is of mistaken tripping due to noise from electromagnetic coupling (crosstalk), inverter switching, and radio frequency (RF) effect. ${ }^{5}$

According to the Solar ABCs report ${ }^{6}$ on the fire safety of PV installations, the PV module fire ratings are useful only for the building integrated PV modules or the modules that are directly mounted on the roof. In case of other configurations of PV installations, such as a rack mount configuration on the roof, the fire safety of the entire system should be considered. Recent work by UL has shown that for rack mounted PV systems the fire rating of the system is dependent on the geometry of the system and not on the fire rating of the module itself. New UL fire tests procedures are expected in late 2012.

\section{Examples of Fire in PV Systems}

It is difficult to quantify the number of PV-initiated fires and to gauge as to how prevalent are fires in PV systems, especially because PV companies do not publicize arcing events. Fortunately, there are no widespread reports on residential fires. PV systems present several concerns for firefighter safety and firefighting operations. ${ }^{7}$ These include energized equipment, trip hazards, restricting venting locations, limiting walking surfaces on roof structures, etc. Sometimes the fires are not caused by the PV array but a fire occurs in a building with a PV array on it. In this case, it is important for fire departments to understand how the PV array changes the way they should fight the fire. Johnson ${ }^{5}$ has provided three examples of documented fires in PV systems, all in commercial installations: Buerstadt, Germany, a commercial building (Fig. 11); Mont Soleil, Switzerland, a560 kW plant; and Bakersfield, California, a Target store caused by electrical arcing (Fig. 12). Figures 13 and 14 illustrate the likely hood of an uninterrupted fault and an undetected fault, respectively, in the Bakersfield fire. The PV system at the Target Store, Bakersfield, California consisted of 1826 Sunpower SPR-210-WHT modules arranged in166 strings of 11 modules each. ${ }^{8}$ The strings were connected to two Xantrex inverters through four fused combiner boxes. The open circuit voltage of the string was $575 \mathrm{~V}$. Its operating current and voltage were $5.25 \mathrm{amps}$ and $440 \mathrm{~V} \mathrm{dc}$, respectively. System conductors, over current protection, and disconnects were installed per approved plan and 2004 California Electric Code (NEC 2002). On May 4, 2009, at 4:20 p.m. when the firefighters arrived a row of nine PV modules in sub array 1 and the roof below were completely engulfed in fire. A 3 in. EMT conduit and the roof below it had also caused a smaller fire $\sim 60 \mathrm{~m}$ away; dc disconnects at the inverters were opened by the first respondents. There were no dc disconnects at the outputs of the combiner boxes since they were not required by the code. An electrical contractor who was called to the scene, had to open fuses in all 56 combiner boxes, insulate exposed string conductors, 


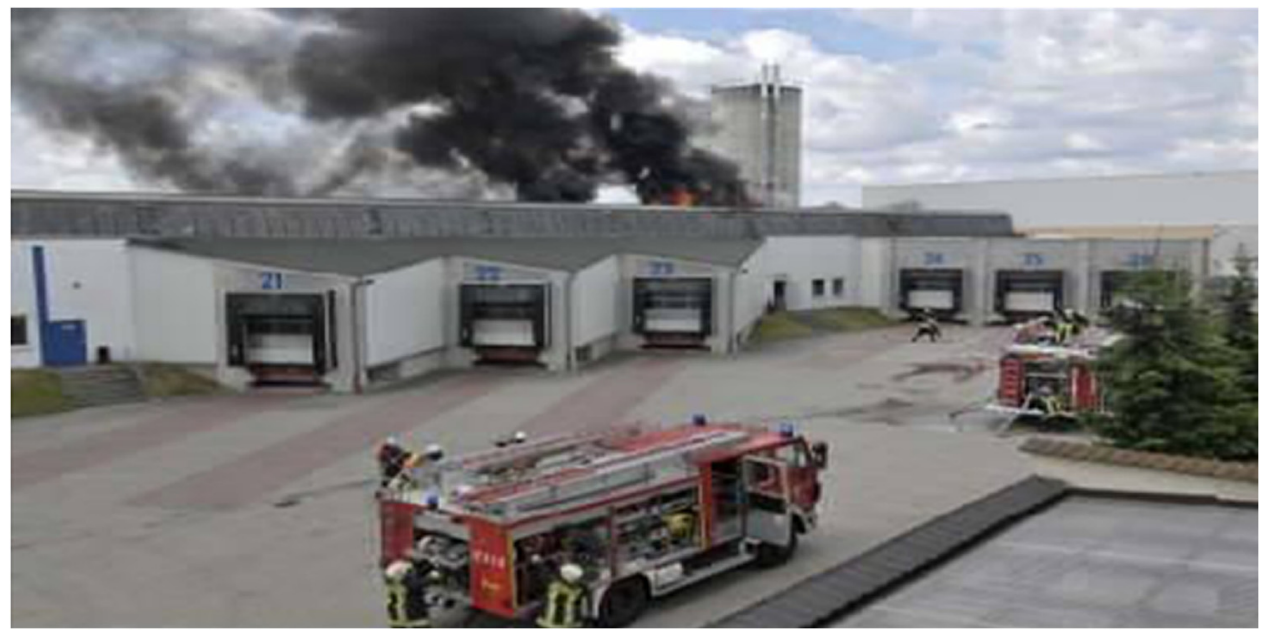

Fig. 11 Rooftop fire at Buerstadt, Germany. Courtesy: Jay Johnson, Sandia National Labs.

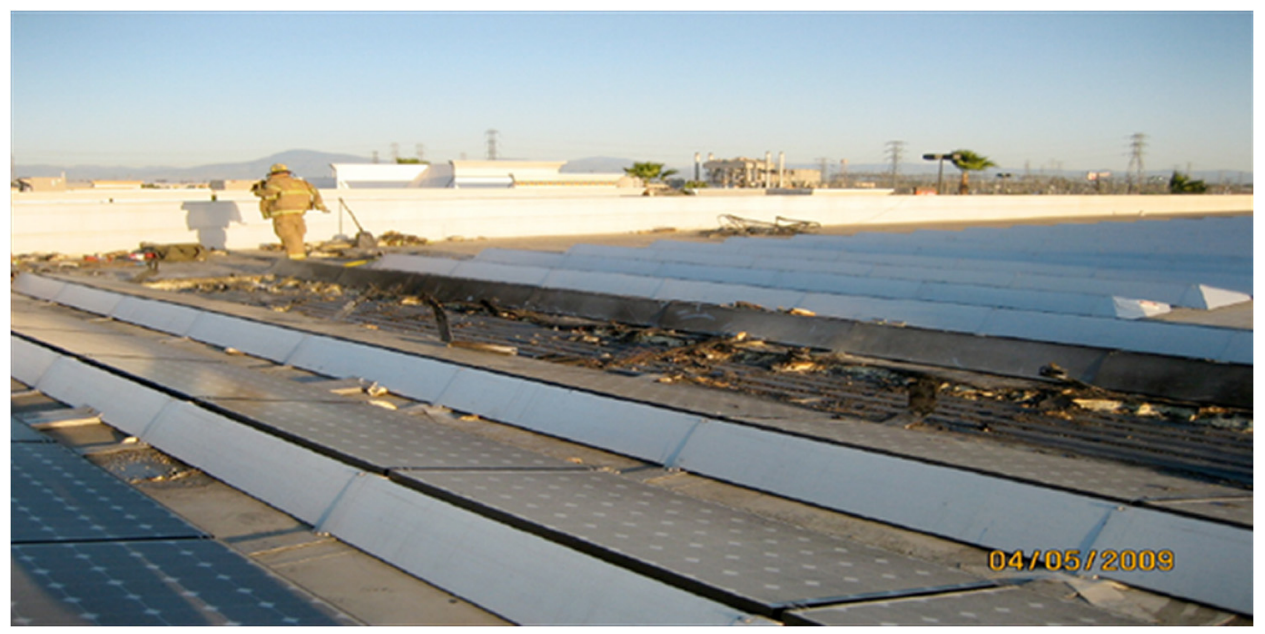

Fig. 12 PV arcing and fire in Target store at Bakersfield, CA.

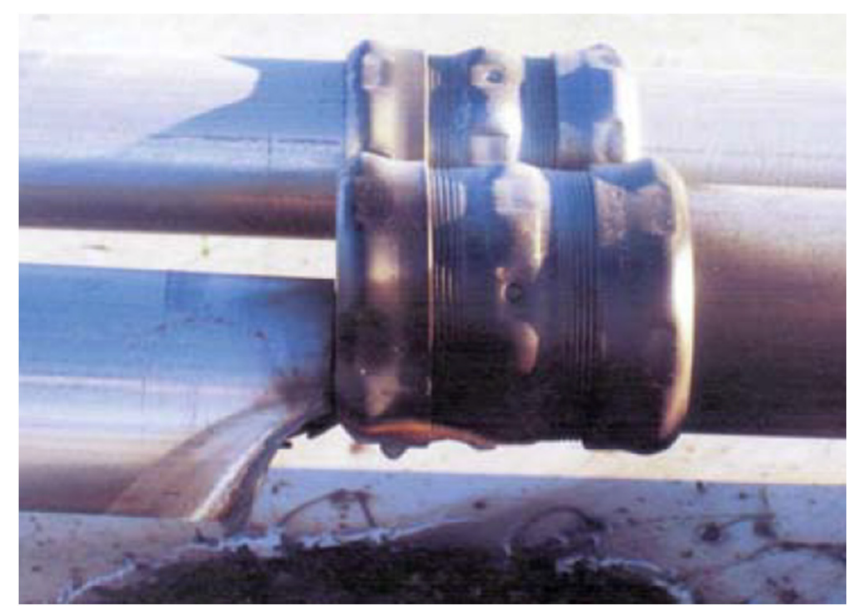

Fig. 13 The failure of an improperly specified and installed expansion joint possibly triggered the Bakersfield fire. ${ }^{9}$ However, this was not the first fault in the system. 


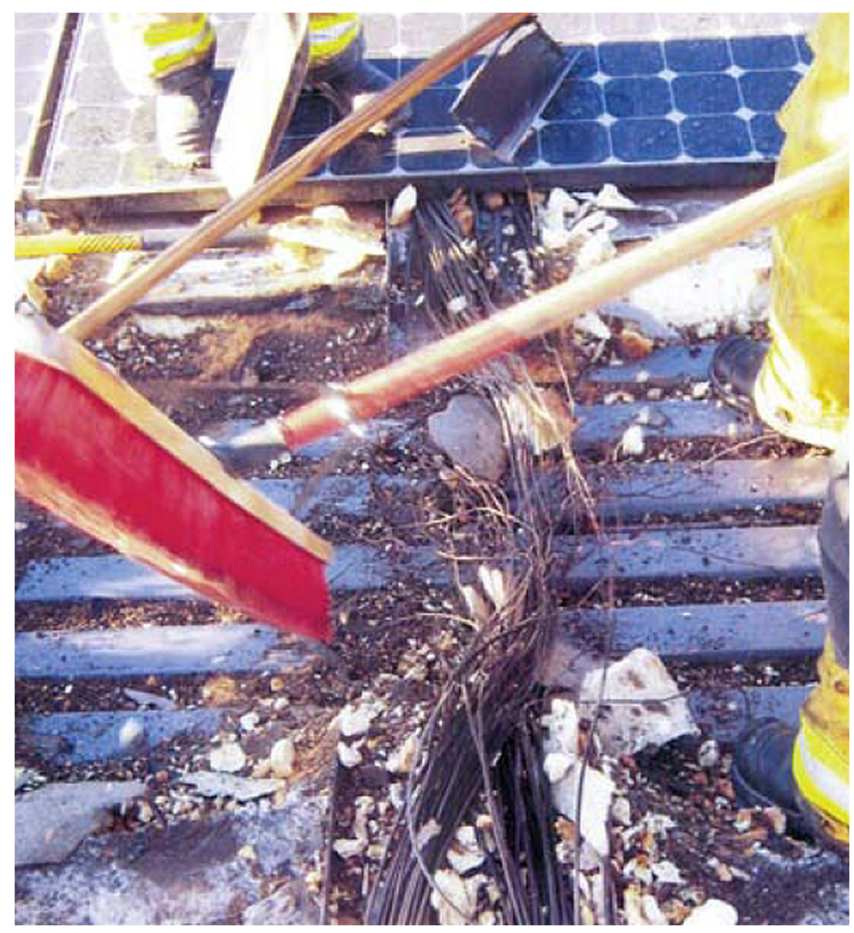

Fig. 14 The possibility of an undetected first fault in PV source-circuit conductors highlights the importance of proper commissioning procedures and improved wire management practices throughout the industry. ${ }^{9}$

and disconnect the combiner output conductors from the combiner box thus isolating the PV modules which continue to generate electricity when exposed to sunlight. ${ }^{8}$ Fortunately, the resulting two-alarm fire did not get past the solar modules or through the roofing materials of the store. This fire happened on a bright sunny day, and the modules continued to generate electricity throughout the event with no easy way to de-energize them. In case of fire, the fire brigade instructs the local utility to cut-off electricity. However, in this case, the responding fire department could not readily isolate the burning modules. It would take an act of God such as causing a temporary eclipse in the epic Mahabharata to cut off the sunlight illuminating the PV system.

In principle, there is a risk of toxic materials evaporating into the air in case of CdTe or CIS thin-film modules affected by fire. But it has been reported ${ }^{10}$ that the roof temperatures in domestic fires in the US are in $800^{\circ} \mathrm{C}$ to $900^{\circ} \mathrm{C}$ range, while CdTe melting point is $1041^{\circ} \mathrm{C}$. Even though the CIS starts evaporating at $600^{\circ} \mathrm{C}$, only $20 \%$ weight loss was measured at $1000^{\circ} \mathrm{C} .^{7}$ Thus, the possibility of considerable photovoltaic material emissions exists only in large externally fed industrial fires. In any case, the fire itself poses much greater hazards than the toxic gas emission.

Now, new fire safety regulations are being formulated and it is being recommended to install an easily accessible and recognizable disconnect switch between the PV array and the power management system. It must be noted that even after disconnecting the PV array from the power management system, the arrays will continue to generate dangerously high dc voltages.

\section{Effect of PV Array on Fire Safety Operations}

Even though the fire may not be caused by the PV array, by its mere presence on the roof, it poses unique challenges to the firefighters. For example, the live dc wires may remain undetected by "hot sticks" that some firefighters use for detecting live wires. ${ }^{11}$ Apart from that, the additional weight of PV array may accelerate the roof collapse if the building structure is already weakened by the fire. The UL report on the firefighter safety and PV installations research project gives several guidelines for the firefighters for dealing with the fires in the building with PV array. Some of those are discussed below: ${ }^{12}$ 
1. Sometimes, firefighters are left with no option but to spray water on live electrical instruments in order to extinguish fire. The electric shock hazard due to application of water depends on voltage, water conductivity, distance, and spray pattern. A spraying distance of $6 \mathrm{~m}$ from a $1000 \mathrm{~V}$ dc source has been determined to be safe.

2. Outdoor rated electrical enclosures are not resistant to water penetration by fire hose streams and may pose an electrical hazard due to collection of water in them. Hence, firefighters need to be careful of such enclosures during the fire safety operations and the enclosures should be dried before turning the power back on.

In general, it can be said that very limited knowledge about dealing with fires in the presence of PV systems exists at present, and there is need to further explore this area.

\section{Recommendations and Conclusions}

The root causes of hot spots, open circuits, and ground faults must be well-understood. In order to prevent the initiation of fire on the roof, the roof and the module must be certified for fire safety and additionally, the installation must be safe. Roof and module certifications by themes are not sufficient because a certified module deployed on a certified roof can lead to fire hazard especially if the mounting structure forms the chimney effect and results in the uncontrollable spread of the fire (Fig. 15). Therefore, the mounting must be certified for fire safety and especially the chimney effect must be avoided. As shown in Fig. 16, this is done by placing deflectors that block the chimney effect but allow air to flow beneath the module to keep them cool.

Bypass and blocking diodes must be chosen carefully and tested adequately. PV systems should not be grounded. A ground fault detector and an arc fault detector should be included in each system. The Newport Beach Fire Department has prepared guidelines on Fire Safety for PV Systems. ${ }^{1}$ PV systems must be marked using weather resistant material so as to provide the emergency respondents appropriate warning and guidance for isolating the system. An easily accessible, recognizable, and well-marked disconnect switch must be installed between the PV

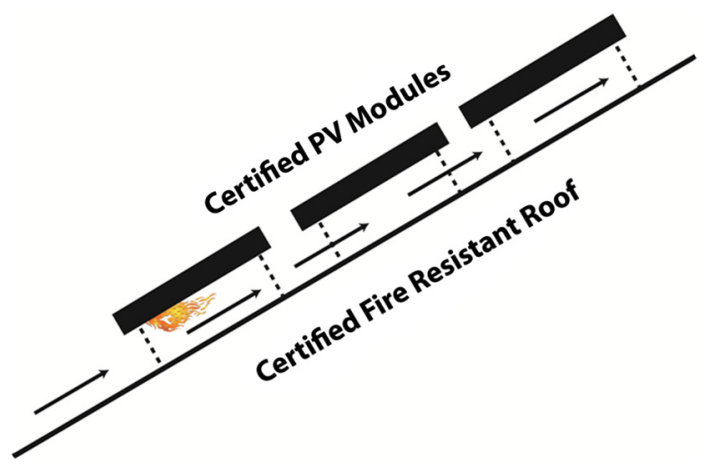

Fig. 15 Chimney effect causing the fire to spread.

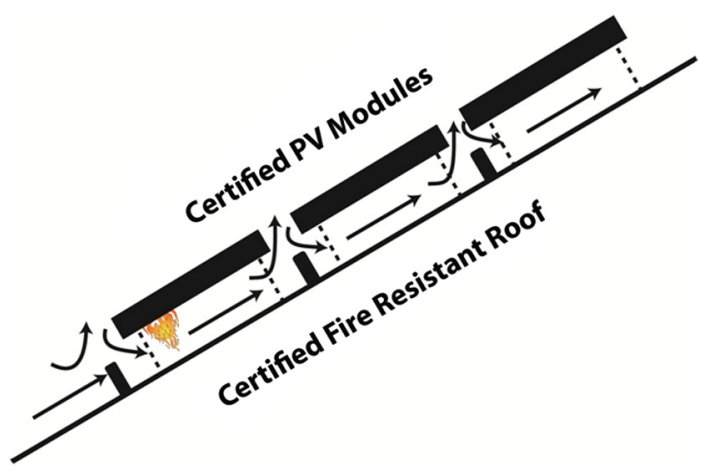

Fig. 16 Prevention of spreading of fire by avoiding the chimney effect with deflectors. 
array and the power management system. Marking should be provided on all interior and exterior dc conduit, raceways, enclosures, cable assemblies, and junction boxes to alert the fire service to avoid cutting them. Adequate access and pathways smoke ventilation must be provided so as to ensure easy access and emergency egress. The array section sizes must be limited with adequate pathways between them and opportunities for proper ventilation of smoke to avoid suffocation. Two examples of the recommended designs of commercial PV systems on roofs extracted from these guidelines are shown in Figs. 17 and 18.

Moreover, the PV community should participate in the formulation of fire safety regulations. Firefighters must be provided special training so that they understand PV systems and can effectively deal with fires on buildings with PV systems. They should be made aware that even after disconnecting the PV array from the power management system, the arrays may continue to generate dangerously high dc voltages. The proposed NEC 2014 would require the automatic disconnect of all dc circuits into segments producing no more than $80 \mathrm{~V}$ when either an arc or a fire are detected. The report from the California office of the state fire marshal describes several incidents of fire in California that were not caused by the PV array but were a result of faulty installation. ${ }^{7}$ Thus, there is need for increasing public awareness about the safety guidelines to be followed during the PV installation itself. ${ }^{7}$ This needs urgent attention, because at

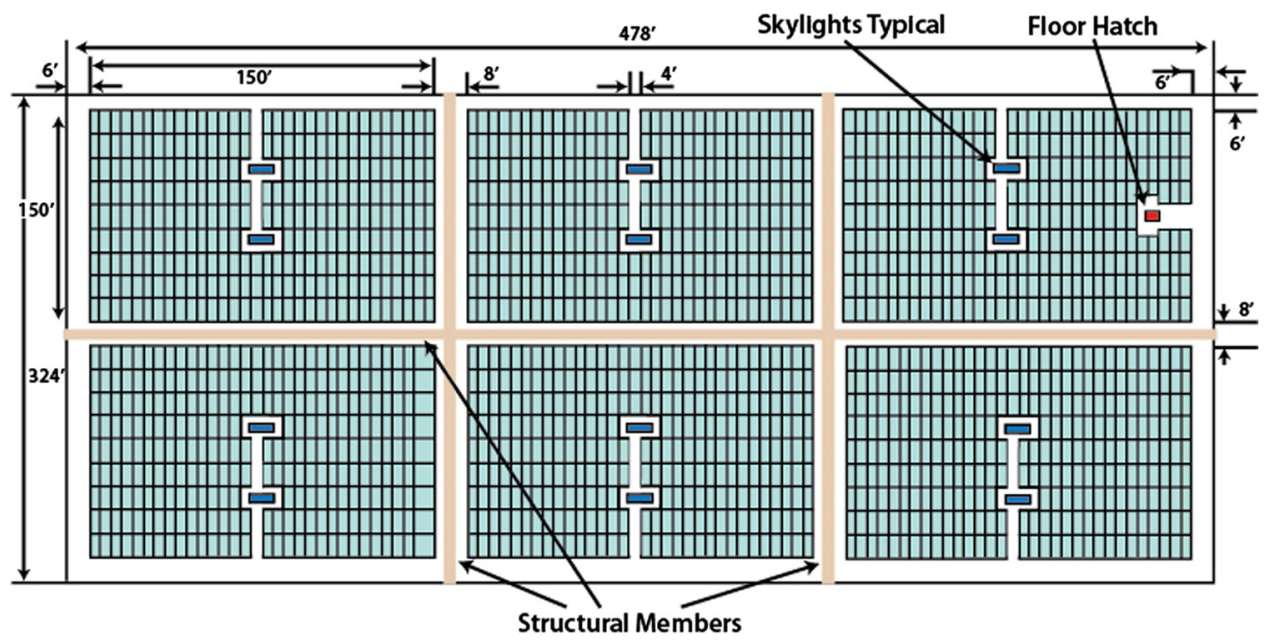

Fig. 17 Safety guidelines ${ }^{7}$ for large commercial PV system (axis $>250$ feet): with 8-foot walkways. Courtesy: Dennis Grubb, assistant fire marshal from Orange County Fire Authority.

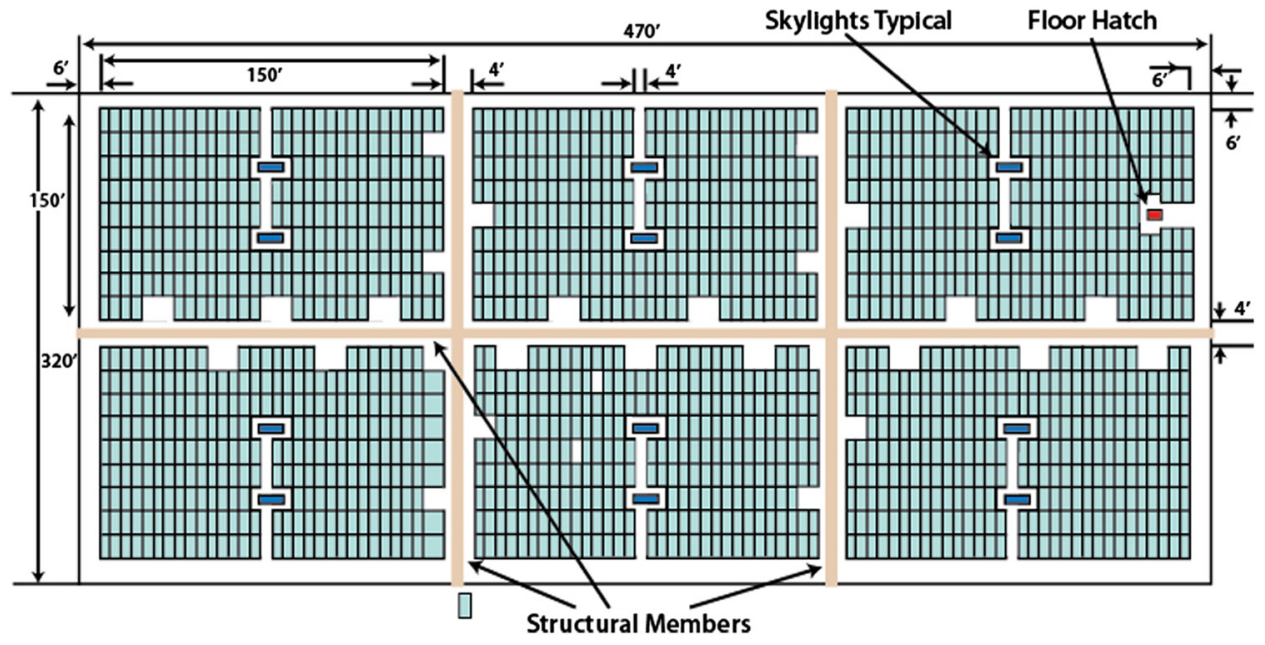

Fig. 18 Guidelines $^{7}$ for large commercial PV system (axis $>250$ feet): with 4-foot walkways, and 8-foot $\times 4$-foot venting opportunities every 20 feet. Courtesy: Dennis Grubb, assistant fire marshal from Orange County Fire Authority. 
times, the firefighters could feel helpless and may simply let a building with a PV system burn down.

\section{Acknowledgments}

The authors are grateful to Dr. Gobind Atmaram, FSEC for arranging to provide five of the degraded a-Si:H modules for analysis, to Dr. John Wohlgemuth, National Renewable Energy Laboratory, for valuable and extensive discussions and for providing several pictures. Without his keen interest, guidance, and help, it would have been impossible to complete this paper. The authors are also thankful to the Newport Beach Fire Department, Tim Zgonena, Underwriters Laboratories, and Jay Johnson, Sandia National Labs for the images and figures.

\section{References}

1. A. Krulewitz, "Top ten US utility PV developers," PV News 30(7), 1, 10-11 (2011).

2. G. TamizhMani and S. Sharma, "Hot spot evaluation of photovoltaic modules," Proc. SPIE 7048, 70480K (2008), http://dx.doi.org/10.1117/12.794245.

3. U. Jahn, Presentation, "Fire tests and fire risks," in International Workshop on BIPV, Nice, France (30 October 2008), http://www.pv-performance.org/performance/project -presentations/workshop-bipv-nice-30-october-2008 (accessed 7 December 2012).

4. "Fire operations for photovoltaic emergencies," CAL-Fire-The Office of the State Fire Marshal, (November 2010), http://osfm.fire.ca.gov (7 December 2012).

5. J. Johnson et al., "Photovoltaic DC Arc Fault Detector testing at Sandia National Laboratories," in 37th IEEE Photovoltaic Specialists Conference, IEEE, Seattle (June 2011).

6. A. Rosenthal et al., "Flammability testing of standard roofing products in the presence of standoff-mounted photovoltaic modules," Solar America Board for Codes and Standards Interim Report, April 2010, http://www.solarabcs.org/about/publications/reports/flammability-testing/ (7 December 2012).

7. "Fire safety elements of solar photovoltaic systems," Building Construction Guidelines, Solar Photovoltaic Systems, Newport Beach Fire Department, Guideline D.04, pp. 12-13, Revised (24 December 2008).

8. P. Jackson, “Target roof PV fire of May 4, 2009," Development Services/Building Department Memorandum, City of Bakersfield, CA (29 April 2009), http://nfpa.typepad.com/files/ target-fire-report-09apr29.pdf (accessed 7 December 2012).

9. B. Brooks, "The Bakersfield fire: a lesson learned in ground-fault protection," Solarpro, Issue 4.2, pp. 62-70 (February-March 2011).

10. V. M. Fthenakis, "Overview of potential hazards," Chapter VII-2 in Practical Handbook of Photovoltaics: Fundamentals and Applications, Elsevier B.V. (2003).

11. N. Gromicko and E. London, "Solar panel fires and electrical hazards," http://www.nachi .org/solar-panel-fire-electrical-hazards.htm (7 December 2012).

12. R. Backstrom and D. Dinni, "Firefighter safety and photovoltaic installations research project," Underwriters Laboratories Inc., 29 November 2011, http:/www.ul.com/global/ documents/offerings/industries/buildingmaterials/fireservice/PV-FF_SafetyFinalReport.pdf (7 December 2012).

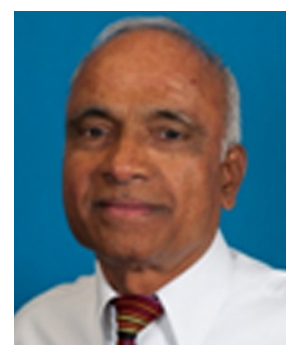

Neelkanth G. Dhere has been working at the Florida Solar Energy Center, University of Central Florida since May 1990. He is program director and joint professor. He worked as professor at Inst Militar de Eng, Rio de Janeiro, Brazil from 1971 to 1990, and as head, Techniques Lab at Physical Research Laboratory, Ahmedabad, India, from 1966 to 1970. He obtained his $\mathrm{PhD}$ from the University of Pune. He has more than 30 years experience in the development of thin-film solar cells, PV module reliability, and side-by-testing PV modules. He is chair for SPIE Reliability of Photovoltaic Cells, Modules, Components, and Systems Conference. He has been 
teaching short courses on polycrystalline thin-film solar cells and design and reliability of PV modules at SPIE and PVSC. He is fellow of AVS SciTechnol. Forty-two students completed MS and $\mathrm{PhD}$ research under his guidance. He is the eldest $\mathrm{PhD}$ in the Family Holding Guinness Book World Record for most doctorates.

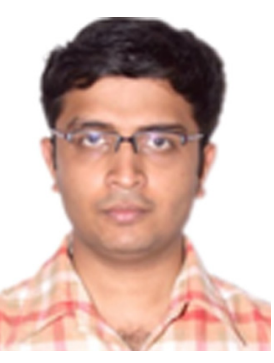

Narendra S. Shiradkar has been pursuing a $\mathrm{PhD}$ in electrical engineering at Florida Solar Energy Center, University of Central Florida since July 2011. He has obtained a dual degree: BTech in electrical engineering and MTech in microelectronics from the Indian Institute of Technology Bombay (2006 to 2011). He has a keen interest in photovoltaics and has been involved in PV research since last 4 years. He has worked on simulation and fabrication of c-Si/a-Si:H heterojunction solar cells during his master's thesis (2010 to 2011). Currently, he is working on PV module reliability and fabrication of CIGSS thin-film solar cells. 